Фармакологічні дослідження біологічно активних речовин Pharmacological researches of biologically active substances

Фармакологічні дослідження біологічно активних речовин ФАРМАЦЕВТИЧНИЙ ЧАСОПИС

http://ojs.tdmu.edu.ua/index.php/pharm-chas

УДК 615.3:615.322:615.26:615.262:615.276

DOI https://doi.org/10.11603/2312-0967.2021.3.12438

\title{
ФАРМАКОЛОГІЧНЕ ДОСЛІДЖЕННЯ КОМБІНОВАНОГО ГЕЛЮ НА ОСНОВІ ЕКСТРАКТІВ ЛІКАРСЬКИХ РОСЛИН ДЛЯ ЛІКУВАННЯ ДЕРМАТОЗІВ
}

\author{
О. Ю. Кошова, В. С. Миргород, О. Г. Башура, С. Г. Бобро, О. П. Єрьомін \\ Національний фрармацевтичний університет МОЗ України \\ svetabobro1@gmail.com
}

\section{ІНФОРМАЦІЯ}

Надійшла до редакції / Received: 01.09.2021

Після доопрацювання / Revised: 13.09.2021

Прийнято до друку / Accepted: 14.09.2021

\section{Ключові слова:}

дерматози;

екстракт листя горіха сухий;

екстракт кропиви сухий;

екстракт чабрецю сухий; гель.

\section{АНОТАЦІЯ}

Мета роботи. Фармакологічне дослідження комбінованого гелю на основі екстрактів лікарських рослин (фрітокомплекс екстрактів листя горіха волоського, кропиви дводомної та чабрецю повзучого) для лікування дерматозів на моделях запалення різного генезу.

Матеріали і методи. На першому етапі проводили визначення протизапальної активності зразків комбінованого гелю на моделі гострого термічного запалення лапи в мишей. Дослідження фрармакологічної активності найефрективніших зразків, за результатами попереднього досліду, проводили на моделі неалергічного контактного дерматиту, препаратом порівняння слугувала мазь «Вундехіл», виробництва ТОВ «ЕЙМ» (Харків, Україна).

Результати й обговорення. На моделі термічного запалення лапи у мишей встановлено, що найбільшу протизапальну активність чинить зразок № 4 із вмістом горіха листя екстракту сухого з сумою танінів у перерахунку на галову кислоту та суху речовину 30 мг/100 г гелю, кропиви екстракту сухого 3 сумою гідроксикоричних кислот у перерахунку на хлорогенову кислоту та суху речовину 20 мг/100 г гелю, чабрецю екстракту сухого 3 сумою срлавоноїдів у перерахунку на рутин та суху речовину 35 мг/100 г гелю, який за ефективністю переважає зразок з окремими рослинними компонентами № 1, 2, 3 та зразки № 5 та 6, в яких вміст сухих екстрактів був збільшений удвічі та утричі відповідно. Активність зразка № 4 була на рівні 80 \%, зразки № 5 та 6 виявили протизапальну активність на рівні 73 \% та $71 \%$.

На моделі неалергічного контактного дерматиту у щурів, модельованого 2,5 \% розчином 2,4-ДНХБ, зразок № 4 виявив виражену есрективність, що підтверджувалося зменшенням клінічних ознак неалергічного контактного дерматиту: зниженням набряку, інтенсивності ураження шкіри та рівня лейкоцитів у крові. За есрективністю зразок № 4 не поступався препарату порівняння мазі «Вундехіл» та переважав таку однокомпонентних зразків № 1, 2, 3.

Висновки. Проведені дослідження на моделях запалення різного генезу показали, що комбінований гель на основі екстрактів лікарських рослин чинить

ISSN 2312-0967. Pharmaceutical review. 2021. № 3 
Фармакологічні дослідження біологічно активних речовин Pharmacological researches of biologically active substances

більш виражену протизапальну дію, ніж його окремі компоненти. Отримані результати обґрунтовують доцільність використання екстрактів листя горіха, кропиви та чабрецю у складі засобу та перспективність подальших фрармакологічних досліджень гелю 3 метою створення ефективного засобу для лікування захворювань шкіри запального генезу.

Вступ. Місцеве лікування запальних захворювань шкіри залишається серйозною проблемою сучасної дерматології. За даними Департаменту МO3 з рефрорм і розвитку медичної допомоги, кожен 20 мешканець України хворіє на один із видів шкірних захворювань [1]. Окрім того, зовнішні клінічні ознаки та свербіж, що нерідко супроводжує дерматози, спричиняють відчутний дискоморорт та суттєво знижують якість життя людини.

Незважаючи на достатньо широкий перелік засобів для місцевої терапії захворювань шкіри, складність та розмаїття змін, що супроводжують їх загоєння, зумовлють певні труднощі лікування дерматозів та актуальність пошуку нових ефективних препаратів [2]. Перспективним джерелом біологічно активних речовин (БАР) є лікарські рослини, раціональне поєднання яких 3 різними допоміжними речовинами та використання оптимальної схеми технології виготовлення м'яких лікарських фрорм для зовнішнього застосування може суттєво розширити терапевтичні можливості фрітопрепаратів у лікуванні і профрілактиці дерматозів та в лікувальній косметології.

На кафредрі косметології та аромології Національного фрармацевтичного університету (НФаУ, Харків, Україна) розроблено комбінований гель на основі екстрактів лікарських рослин для лікування дерматозів неалергічного генезу. До складу комбінованого гелю входять екстракти рослин, що широко застосовуються для лікування дерматозів різної етіології: екстракт листя горіха волоського, кропиви дводомної та чабрецю повзучого. У роботі використовували стандартизовані сухі екстракти виробництва ТОВ «Науково-виробнича компанія «Віларус» (Україна): горіха листя екстракт сухий - вміст суми танінів у перерахунку на галову кислоту та суху речовину 2,89 \%; кропиви екстракт сухий - вміст суми гідроксикоричних кислот у перерахунку на хлорогенову кислоту та суху речовину - 2,04 \%; чабрецю екстракт сухий вміст суми фрлавоноїдів у перерахунку на рутин та суху речовину - 3,23 \%. Поєднання біологічно активних речовин різних фрункціональних груп сприятиме комбінованому впливу на патологічні процеси дерматозів.

Мета роботи - фрармакологічне дослідження комбінованого гелю на основі екстрактів лікарських рослин (фрітокомплекс екстрактів листя горіха волоського, кропиви дводомної та чабрецю повзучого) для лікування дерматозів на моделях запалення різного генезу.
Матеріали і методи. Дослідження були проведені на мишах і щурах (самцях), що утримувалися у віварії ННІПФ НФаУ на стандартному харчуванні відповідно до рекомендованих норм [3]. 3 тваринами поводились згідно з правилами «Європейської конвенції по захисту хребетних тварин, яких використовують для експериментальних та наукових цілей» (Страсбург, 1986 р) [4]. Проект плану фрармакологічного дослідження комбінованого гелю з фрітокомплексом для лікування захворювань шкіри був схвалений комітетом із біоетики НФаУ (протокол № 1 від 2020 р.). Дослідженню підлягали зразки із вмістом горіха листя екстракту сухого з сумою танінів у перерахунку на галову кислоту та суху речовину 30 мг/100 г гелю, кропиви екстракту сухого з сумою гідроксикоричних кислот у перерахунку на хлорогенову кислоту та суху речовину 20 мг/100 г гелю, чабрецю екстракту сухого з сумою фрлавоноїдів у перерахунку на рутин та суху речовину 35 мг/100 г гелю.

Об'єктом дослідження слугували 3 зразки комбінованого гелю $з$ фрітокомплексом із різним вмістом активних діючих речовин - екстрактів листя горіха, кропиви та чабрецю: № 4 (по 30 мг/100 г, 20 мг/100 г та 35 мг/100 г кожного екстракту відповідно), № 5 (по 60 мг/100 г, 40 мг/100 г та 70 мг/100 г кожного екстракту відповідно), № 6 (по 90 мг/100 г, 60 мг/100 г та 105 мг/100 г кожного екстракту відповідно). Їхню ефективність порівнювали зі зразками гелю під шифрами № 1, № 2, № 3, що містили тільки один компонент екстракт листя горіха, кропиви або чабрецю відповідно у кількості по 30 мг/100 г, 20 мг/100 г та 35 мг/100 г. На першому етапі проводили визначення протизапальної активності зразків комбінованого гелю на моделі гострого термічного запалення лапи у мишей, яка $€$ зручною моделлю для проведення скринінгових досліджень [5]. Дослід проведено на 50 білих мишах самцях з вихідною масою 20-24 г, яких поділили на 7 груп: 1 група - позитивний контроль (ПК, 8 особин); 2-7 групи - тварини, яким наносили досліджувані гелі під шисррами № 1, 2, 3, 4, 5, 6 відповідно (по 7 тварин). Досліджувані зразки наносили у дозі 0,25 г/100 г тварини двічі на день - одразу після опіку та через 2 години після нього, наступного дня нанесення зразків гелю повторювали. Для оцінки виразності зменшення набряку лапи у піддослідних тварин під дією досліджуваних зразків, порівняно з групою ПК, розраховували індекс реакції за фрормулою та виражали у \%:

$$
I P=(Р п к-\text { Рд)/Рпк×100\%, }
$$

ISSN 2312-0967. Фармацевтичний часопис. 2021. № 3 
Фармакологічні дослідження біологічно активних речовин

Pharmacological researches of biologically active substances

де Рд - середня різниця в масі між набряклою здоровою лапами у дослідній групі, мг; Рпк - середня різниця в масі між набряклою і здоровою лапами у групі ПК, мг.

Дослідження фрармакологічної активності найесрективніших зразків, визначених у попередньому досліді, проводили на моделі неалергічного контактного дерматиту (НКД). Експеримент проведено на 30 білих нелінійних щурах-самцях масою 240-250 г.

3 огляду на те, що на фрармацевтичному ринку України відсутні препарати-аналоги досліджуваного гелю за складом рослинних екстрактів, препарат порівняння обирали за принципом тотожності фрармакологічної дії досліджуваного засобу. 3 тієї точки зору препаратом порівняння було обрано багатокомпонентний засіб - мазь «Вундехіл» (с. V 31D1 6), виробництва ТОВ «ЕЙМ» (Харків, Україна), що виявляє аналогічну фрармакологічну дію. Клінічні дослідження свідчать, що мазь «Вундехіл» $€$ еорективним лікарським засобом для місцевого лікування запальних захворювань шкіри різного генезу, завдяки активації репаративних процесів (грануляції та епітелізації), добре переноситься пацієнтами та не викликає побічної дії [6].

Тварин розподілили на 6 груп по 5 щурів у кожній: 1 група - позитивний контроль (ПК); 2-4 групи - тварини, яким наносили досліджувані монокомпонентні гелі під шифрами № 1, 2, 3; 5 група - тварини, яким наносили комбінований гель з фрітокомплексом № 4; 6 група - тварини, яким наносили препарат порівняння мазь «Вундехіл».

Неалергічний контактний дерматит моделювали шляхом щоденного нанесення на вистрижену ділянку шкіри (площею 4х4 см) щурів 2 крапель 2,5 \% розчину 2,4-динітрохлорбензолу (2,4- ДНХБ) впродовж
5 днів. Інтенсивність розвиненого дерматиту оцінювали візуально за виразністю запальної реакції шкіри, яку виражали у балах за загальноприйнятою шкалою [7], товщину шкірної згортки тварин виміряли за допомогою штангенциркуля до початку експерименту, на 6-й, 8-й та 12-й день, рівень лейкоцитів у периферичній крові щурів досліджували перед початком лікування (6-й) та через 7 діб (12-й день експерименту).

Нанесення досліджуваних зразків № 1, № 2, № 3, № 4 та препарату порівняння (ПП) мазі «Вундехіл» починали на 6 добу експерименту та продовжували щодня впродовж 7 діб.

Отримані результати обробляли методами варіаційної статистики, вираховували середнє арифметичне (M) та його стандартну похибку (m) або мінімальне (min) та максимальне (max) значення та медіанне значення (Me), нижній (Q25) та верхній (Q75) квартилі. Для отримання статистичних висновків використовували параметричні (критерії Ньюмана Кейлса) або непараметричні (критерій Манна - Уїтні) методи. Відмінності між експериментальними групами вважали статистично значущими при $p<0,05$. Для проведення математичних розрахунків застосовували стандартний пакет статистичних програм «Statistica 6,0».

Результати й обговорення. Відповідно до отриманих даних, після опіку маса ушкодженої лапи у тварин з групи ПК збільшилась у середньому на $13 \%$ (табл. 1), що свідчило про розвиток помірного набряку лапи мишей. Нанесення досліджуваних зразків суттєво знижувало виразність набряку - індекс реакції запалення (IP, табл. 1) був статистично значуще нижчим порівняно з показниками у групі ПК. 3 даних, наведених у таблиці 1 видно, що еорективність зразків № 4, 5, 6 була вища, ніж у монокомпонентних

\section{Таблиця 1}

Протизапальна дія зразків № 4, 5, 6 порівняно 3 монокомпонентними зразками № 1, 2, 3, за умови гострого термічного запалення лапи у мишей, $\mathrm{n}=8-7$

\begin{tabular}{|c|c|c|c|}
\hline \multirow{2}{*}{ Групи тварин } & \multicolumn{3}{|c|}{ Індекс реакції запалення, \% } \\
\hline & $M(\min \div \max )$ & Me (Q25;Q75) & ПЗА, \% \\
\hline Позитивний контроль & $12,7(7,95 ; 22,73)$ & $12,3(8,24 ; 15,03)$ & - \\
\hline Зразок № 1 (горіха листя екстракт сухий 30 мг/100 г) & $6,4(1,39 ; 20,56)^{\star / * *}$ & $4,4(3,16 ; 6,76)^{\star / \star \star}$ & 50 \\
\hline Зразок № 2 (кропиви екстракт сухий 20 мг/100 г) & $3,7(1,07 ; 8,44)^{\star}$ & $2,4(1,70 ; 6,45)^{\star}$ & 71 \\
\hline Зразок № 3 (чабрецю екстракт сухий 35 мг/100 г) & $7,1(1,28 ; 19,76)^{\star / * \star}$ & $5,8(2,98 ; 9,42)^{\star / \star \star}$ & 44 \\
\hline $\begin{array}{l}\text { Зразок № } 4 \text { (по } 30 \text { мг/100 г, } 20 \text { мг/100 г та } 35 \text { мг/100 г } \\
\text { кожного екстракту відповідно) }\end{array}$ & $2,5(1,28 ; 3,91)^{\star}$ & $2,6(1,31 ; 3,57)^{\star}$ & 80 \\
\hline $\begin{array}{l}\text { Зразок № } 5 \text { (по } 60 \text { мг/100 г, } 40 \text { мг/100 г та } 70 \text { мг/100 г } \\
\text { кожного екстракту відповідно) }\end{array}$ & $3,5(0,54 ; 7,33)^{\star}$ & $2,4(1,39 ; 7,03)^{\star}$ & 73 \\
\hline $\begin{array}{l}\text { Зразок № } 6 \text { (по } 90 \text { мг/100 г, } 60 \text { мг/100 г та } 105 \text { мг/100 } \\
\text { г кожного екстракту відповідно) }\end{array}$ & $3,7(0,62 ; 12,50)^{\star}$ & $1,7(1,00 ; 4,55)^{\star}$ & 71 \\
\hline
\end{tabular}

Примітки: 1) * - відмінності статистично значущі щодо групи позитивного контролю, $p<0,05$;

2) ** - відмінності статистично значущі щодо зразка № 7, p<0,05.

ISSN 2312-0967. Pharmaceutical review. 2021. № 3 
Фармакологічні дослідження біологічно активних речовин Pharmacological researches of biologically active substances

зразків досліджуваного гелю. Крім того, у даному експерименті зразок № 4 виявив найбільшу ефективність (80 \%): IP у цій групі тварин був статистично значуще нижче, ніж у групах тварин, яким наносили монокомпонентні зразки гелю № 1 і № 3.

Згідно 3 рекомендаціями із дослідження нових фармакологічних засобів для подальшого вивчення обирають зразок, що виявив максимальну ефективність в найменшій дозі або (у випадку зразків для нашкірного застосування) 3 найменшим вмістом активно діючих речовин. Отже, незважаючи на те, що статистичних відмінностей між досліджуваними зразками № 4, 5, 6 не встановлено, для подальшого вивчення був обраний зразок № 4, який виявляє найбільшу ефективність та містить найменшу кількість екстрактів листя горіха, кропиви та чабрецю. Отримані дані свідчать про доцільність використання екстрактів цих лікарських рослин у складі засобу саме у таких концентраціях.
На другому етапі дослідження визначали протизапальні та репаративні властивості зразку № 4 на моделі НКД порівняно з монокомпонентними зразками № 1, 2, 3 та маззю «Вундехіл».

Згідно з отриманими даними (табл. 2) щоденні аплікації ДНХБ провокували ушкодження шкіри у тварин усіх експериментальних груп, яке характеризувалося вираженим набряком прилеглих тканин, про що свідчило збільшення товщини шкірної згортки в 2 рази порівняно 3 вихідними даними на 5 добу, інорільтрацією та утворенням геморагічних кірок із виразками (інтенсивність запалення шкіри у середньому відповідала 4,0 балам). На 8-й та 10-й день експерименту внаслідок спонтанної регенерації прояви ураження шкіри у тварин з групи ПК знижувалися, але залишалися достатньо виразними та статистично значуще вищими порівняно з вихідними значеннями: інтенсивність запалення склала 2,8-3,6 балів, залишалася виразною набряклість шкіри - товщина складки дорівнювала 3,2-3,8 мм (див. табл. 2).

\section{Таблиця 2}

Вплив зразків № 1, 2, 3, комбінованого гелю з фрітокомплексом № 4 та препарату порівняння мазі «Вундехіл» на інтенсивність ураження шкіри за умови неалергічного контактного дерматиту щурів, спричиненого 2,5 \% ДНХБ, $\mathrm{M} \pm \mathrm{m}, \mathrm{n}=6$

\begin{tabular}{|c|c|c|c|c|c|c|c|}
\hline \multirow{3}{*}{ Групи тварин } & \multicolumn{7}{|c|}{ Періоди спостереження, доба } \\
\hline & \multirow{2}{*}{$\begin{array}{c}\begin{array}{c}\text { Вихідний } \\
\text { стан }\end{array} \\
\text { товщина } \\
\text { згортки, мм }\end{array}$} & \multicolumn{2}{|c|}{$\begin{array}{c}5 \text { доба досліду } \\
\text { (0 день лікування) }\end{array}$} & \multicolumn{2}{|c|}{$\begin{array}{c}8 \text { доба досліду } \\
\text { (3 день лікування) }\end{array}$} & \multicolumn{2}{|c|}{$\begin{array}{c}10 \text { доба досліду } \\
\text { (5 день лікування) }\end{array}$} \\
\hline & & $\begin{array}{c}\text { товщина } \\
\text { згортки, мм }\end{array}$ & $\begin{array}{c}\text { реакція } \\
\text { шкіри, } \\
\text { бали }\end{array}$ & $\begin{array}{c}\text { товщина } \\
\text { згортки, мм }\end{array}$ & $\begin{array}{c}\text { реакція } \\
\text { шкіри, } \\
\text { бали }\end{array}$ & $\begin{array}{c}\text { товщина } \\
\text { згортки, мм }\end{array}$ & $\begin{array}{c}\text { реакція } \\
\text { шкіри, } \\
\text { бали }\end{array}$ \\
\hline $\begin{array}{l}\text { Позитивний } \\
\text { контроль }\end{array}$ & $\begin{array}{l}2,0 \pm \\
0,28\end{array}$ & $\begin{array}{c}4,02 \pm \\
0,12 \\
* \star\end{array}$ & $\begin{array}{l}4,0 \pm \\
0,00\end{array}$ & $\begin{array}{c}3,80 \pm \\
0,29 \\
\star *\end{array}$ & $\begin{array}{l}3,6 \pm \\
0,24\end{array}$ & $\begin{array}{c}3,22 \pm \\
0,21 \\
\star \star\end{array}$ & $\begin{array}{l}2,8 \pm \\
0,20 \\
\star *\end{array}$ \\
\hline $\begin{array}{l}\text { Зразок № } 1 \text { (горіха } \\
\text { листя екстракт } \\
\text { сухий } 30 \text { мг/100 г) }\end{array}$ & $\begin{array}{c}2,04 \pm \\
0,16\end{array}$ & $\begin{array}{l}4,04 \pm \\
0,10 \\
\star \star\end{array}$ & $\begin{array}{l}4,0 \pm \\
0,00\end{array}$ & $\begin{array}{l}3,22 \pm \\
0,10 \\
\star / \star \star\end{array}$ & $\begin{array}{l}2,8 \pm \\
0,37\end{array}$ & $\begin{array}{c}2,70 \pm \\
0,17 \\
\star \star\end{array}$ & $\begin{array}{l}1,4 \pm \\
0,51 \\
*\end{array}$ \\
\hline $\begin{array}{l}\text { 3разок № } 2 \\
\text { (кропиви екстракт } \\
\text { сухий } 20 \text { мг/100 г) }\end{array}$ & $\begin{array}{c}1,84 \pm \\
0,20\end{array}$ & $\begin{array}{c}3,90 \pm \\
0,15 \\
\star *\end{array}$ & $\begin{array}{l}4,0 \pm \\
0,00\end{array}$ & $\begin{array}{c}3,18 \pm \\
0,18 \\
T^{\star} / * \star\end{array}$ & $\begin{array}{l}2,6 \pm \\
0,24\end{array}$ & $\begin{array}{c}2,78 \pm \\
0,21 \\
\star \star\end{array}$ & $\begin{array}{l}1,4 \pm \\
0,40 \\
\star / * \star\end{array}$ \\
\hline $\begin{array}{l}\text { Зразок № } 3 \\
\text { (чабрецю екстракт } \\
\text { сухий } 35 \text { мг/100 г) }\end{array}$ & $\begin{array}{c}2,02 \pm \\
0,26\end{array}$ & $\begin{array}{c}4,02 \pm \\
0,24 \\
\star *\end{array}$ & $\begin{array}{l}4,0 \pm \\
0,00\end{array}$ & $\begin{array}{c}3,40 \pm \\
0,24 \\
\star *\end{array}$ & $\begin{array}{c}2,6 \pm \\
0,24 \\
\star \star\end{array}$ & $\begin{array}{c}2,70 \pm \\
, 04 \\
\star / T^{\star \star}\end{array}$ & $\begin{array}{l}1,8 \pm \\
0,20 \\
\star / * *\end{array}$ \\
\hline $\begin{array}{l}\text { 3разок № } 4 \\
\text { (по } 30 \text { мг/100 } \\
\text { г, } 20 \text { мг/100 г } \\
\text { та } 35 \text { мг/100 г } \\
\text { кожного екстракту } \\
\text { відповідно) }\end{array}$ & $\begin{array}{c}2,02 \pm \\
0,16\end{array}$ & $\begin{array}{c}4,12 \pm \\
0,15 \\
\star \star\end{array}$ & $\begin{array}{l}4,0 \pm \\
0,00\end{array}$ & $\begin{array}{c}3,26 \pm \\
0,11 \\
T^{\star / \star \star}\end{array}$ & $\begin{array}{l}2,4 \pm \\
0,40 \\
\star *\end{array}$ & $\begin{array}{c}2,52 \pm \\
0,10 \\
\star / * \star\end{array}$ & $\begin{array}{l}1,4 \pm \\
0,40 \\
\star / \star \star\end{array}$ \\
\hline Мазь «Вундехіл» & $\begin{array}{l}2,0 \pm \\
0,13\end{array}$ & $\begin{array}{c}3,84 \pm \\
0,09 \\
\star *\end{array}$ & $\begin{array}{l}4,0 \pm \\
0,00\end{array}$ & $\begin{array}{c}3,06 \pm \\
0,12 \\
* / * \star\end{array}$ & $\begin{array}{c}2,8 \pm \\
0,20 \\
\star \star\end{array}$ & $\begin{array}{c}2,64 \pm \\
0,13 \\
* / * *\end{array}$ & $\begin{array}{l}1,8 \pm \\
0,20 \\
\star / * \star\end{array}$ \\
\hline
\end{tabular}

Примітки: 1)* - відмінності статистично значущі щодо тварин із групи позитивного контролю у відповідний термін дослідження, $p<0,05$;

2) ${ }^{\star \star}$ - відмінності статистично значущі щодо вихідних даних, p<0,05.

ISSN 2312-0967. Фармацевтичний часопис. 2021. № 3 
Фармакологічні дослідження біологічно активних речовин

Pharmacological researches of biologically active substances

При застосуванні досліджуваних зразків спостерігали позитивну динаміку загоєння ран. Найефективнішу дію чинив зразок № 4, на тлі застосування якого інтенсивність ураження шкіри та набряк прилеглих тканин поступово зменшувалися. 3 3-ї доби лікування товщина шкірної згортки та виразність запальної реакції статистично значуще зменшувалися порівняно з показниками тварин із групи ПК. За ефрективністю досліджуваний зразок не поступався ПП мазі «Вундехіл». Динаміка загоєння НКД при застосуванні монокомпонентних зразків була однонаправленою зі зразком № 4, але дещо нижчою за виразністю (див. табл. 2).

Безпосереднє пошкодження епідермісу внаслідок нанесення 2,5 \% розчину ДНХБ тваринам провокує вивільнення гістаміну та інших медіаторів запалення і хемотоксичних фракторів опасистими клітинами, що призводить до розширення судин (еритема), виходу рідини у дерму та епідерміс (набряк) та клітинної інфрільтрації імунокомпетентних клітин у місце пошкодження. В ураненому місці спочатку виявляється лімфоцитарна, потім нейтрофрільна інфрільтрація, спостерігається внутрішньоклітинний та зовнішньоклітинний набряк епідермісу. Вищенаведені ознаки свідчать про мобілізацію пулу лімфроцитів, спрямовану для усунення пошкодження, що відображається характерним для даного запального процесу підвищенням кількості лейкоцитів у крові тварин. На піку пато- логії (5 доба експерименту) кількість лейкоцитів була вищою в 1,5-1,7 раза порівняно 3 показниками інтактного контролю. Наведені зміни були статистично значущими (табл. 3).

Таким чином, аналіз отриманих даних дає підставу зробити висновок, що застосування досліджуваного зразку № 4 суттєво знижує прояви неалергічного контактного дерматиту у щурів, що підтверджується зменшенням набряку шкіри (на $22 \%$, р<0,05) та інтенсивності її ураження (на $50 \%$, р<0,05) і зниженням кількості лейкоцитів на $33 \%(p<0,05)$ порівняно 3 групою ПК. Необхідно зазначити, що активність зразку № 4 була в 1,2-1,5 раза вища порівняно 3 активністю монокомпонентних зразків № 1, 2 та 3. Поєднання фрармакологічних властивостей біологічно активних речовин екстрактів листя горіха, кропиви та чабрецю у складі комбінованого фрітокомплексу (зразок № 4) посилює ефективність окремих екстрактів та сприяє більш виразному зменшенню інтенсивності набряку, еритеми та лейкоцитозу. За даними літератури, лікарські рослини, що входять до складу комбінованого фрітокомплексу № 4, проявляють кровоспинну, протимікробну та протизапальну дію, нормалізують обмін речовин та підвищують неспецифічну резистентність організму, що й зумовлює ефективність досліджуваного зразка на даній експериментальній моделі.

\section{Таблиця 3}

Вплив зразків № 1, 2, 3, комбінованого гелю з фрітокомплексом № 4 та препарату порівняння мазі «Вундехіл» на

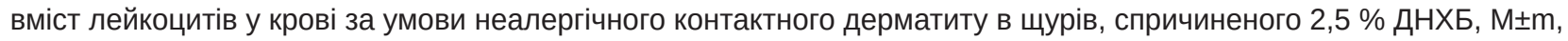
$\mathrm{n}=6$

\begin{tabular}{|l|c|c|}
\hline \multirow{2}{*}{ Групи тварин } & \multicolumn{2}{c|}{ Лейкоцити, 10\%/л } \\
\cline { 2 - 3 } & $\begin{array}{c}\text { 5 доба досліду } \\
\text { (пік патології) }\end{array}$ & $\begin{array}{c}10 \text { доба досліду } \\
\text { (5 доба лікування) }\end{array}$ \\
\hline Інтакт & $11,10 \pm 0,51$ & $11,90 \pm 0,41$ \\
\hline Позитивний контроль & $18,70 \pm 0,86^{\star}$ & $15,45 \pm 0,37^{\star}$ \\
\hline Зразок № 1 (горіха листя екстракт сухий 30 мг/100 г) & $18,65 \pm 0,61^{*}$ & $12,65 \pm 0,41^{\star *}$ \\
\hline Зразок № 2 (кропиви екстракт сухий 20 мг/100 г) & $17,10 \pm 1,02^{\star}$ & $13,00 \pm 0,69^{\star *}$ \\
\hline Зразок № 3 (чабрецю екстракт сухий 35 мг/100 г) & $18,85 \pm 0,93^{\star *}$ \\
\hline $\begin{array}{l}\text { Зразок № 4 (по 30 мг/100 г, 20 мг/100 г та 35 мг/100 г } \\
\text { кожного екстракту відповідно) }\end{array}$ & $18,35 \pm 0,93^{\star}$ & $11,65 \pm 0,88^{\star \star}$ \\
\hline Мазь «Вундехіл» & $18,05 \pm 0,88^{\star}$ & $12,55 \pm 0,56^{\star *}$ \\
\hline
\end{tabular}

Примітки: 1) * - відмінності статистично значущі щодо групи тварин інтактного контролю у відповідний термін дослідження, $p<0,05$;

2) ** - відмінності статистично значущі щодо групи тварин позитивного контролю, p<0,05.

Висновки. 1. На моделі гострого термічного опіку лапи мишей встановлено більш виразну протизапальну дію зразків у вигляді гелю на основі фрітокомплексів № 4, 5, 6 порівняно 3 однокомпонентними зразками № 1, 2, 3, що містили тільки екстракти окре- мих рослин. Найбільшу активність - на рівні $80 \%$, виявив зразок № 4 (із вмістом горіха листя екстракту сухого, кропиви екстракту сухого, чабрецю екстракту сухого). Зразки № 5 та № 6 виявили протизапальну активність на рівні 73 \% та $71 \%$ відповідно.

ISSN 2312-0967. Pharmaceutical review. 2021. № 3 
Фармакологічні дослідження біологічно активних речовин

Pharmacological researches of biologically active substances

2. На моделі НКД, модельованого 2,4-ДНХБ, зразок № 4 виявив виражену фрармакотерапевтичну ефективність, що підтверджувалося зменшенням клінічних ознак НКД: зниженням набряку, інтенсивності ураження шкіри та рівня лейкоцитів у крові. За есрективністю зразок № 4 не поступався ПП мазі «Вундехіл» та переважав таку монокомпонентних зразків № 1, 2, 3.

3. Отримані результати обґрунтовують доцільність

використання фрітокомплексу біологічно-активних речовин екстрактів листя горіха, кропиви та чабрецю у складі засобу та перспективність подальших фрармакологічних досліджень гелю з метою створення ефективного засобу для лікування захворювань шкіри запального генезу.

Конфрлікт інтересів: відсутній.

Conflicts of interest: authors have no conflict of interest to declare.

\title{
PHARMACOLOGICAL STUDY OF COMBINED GEL BASED ON EXTRACTS OF MEDICINAL PLANTS FOR TREATMENT OF SKIN DISEASES
}

\author{
O. Yu. Koshova, V. S. Myrhorod, O. G. Bashura, S. G. Bobro, O. P. Yeromin \\ National University of Pharmacy \\ svetabobro1@gmail.com
}

The aim of the work. The study aimed to select the optimal composition of the combined gel based on dry extracts of walnut leaves, nettle, and creeping thyme for the treatment of skin diseases and the study of its pharmacological properties in models of inflammation of different genesis.

Materials and Methods. At the first stage, the anti-inflammatory activity of the combined gel samples was determined in a model of acute thermal paw inflammation in mice. Studies of the pharmacological activity of the most effective samples identified in the previous experiment were performed on a model of non-allergic contact dermatitis, the comparison drug was ointment "Woundeheal", manufactured by "AIM" (Kharkiv, Ukraine).

Results and Discussion. In the model of thermal inflammation of the paw in mice, it was found that the greatest antiinflammatory activity has TS No. 4 with walnut leaf extract with the number of tannins in terms of gallic acid and dry matter $35 \mathrm{mg} / 100 \mathrm{~g}$ gel, nettle extract with the number of hydroxycinnamic acids in terms for chlorogenic acid and dry matter $20 \mathrm{mg} / 100 \mathrm{~g}$ of gel, thyme extract dry with the number of flavonoids in terms of rutin and dry matter $30 \mathrm{mg} / 100 \mathrm{~g}$ of gel, which is more effective than TS with individual plant components No. 1, 2, 3 and TS No. 5 and 6, in which the content of dry extracts was doubled and tripled, respectively. The activity of TS No. 4 was at the level of $80 \%$, TS No. 5 and 6 showed anti-inflammatory activity at the level of $73 \%$ and $71 \%$.

In the model of non-allergic contact dermatitis in rats, modeled with $2.5 \%$ solution of 2,4-Dinitrochlorobenzene, TS No. 4 showed a pronounced efficacy, which was confirmed by a decrease in clinical signs of non-allergic contact dermatitis: reduced edema, skin lesion intensity, and white blood cell count. The efficiency of TS No. 4 was not inferior to the comparison drug ointment "Woundeheal" and prevailed over monocomponent samples No. 1, 2, 3.

Conclusions. Studies prove the feasibility of combining biologically active substances of walnut leaves, nettle, and thyme extracts in the phytocomplex, which results in synergism and enhancement of the pharmacological properties of individual components.

Key words: dry walnut leaf extract; dry nettle extract; dry thyme extract; gel; non-allergic contact dermatitis; skin diseases.

\section{Перелік бібліографрічних посилань}

1. Дерматологія, венерологія / за ред. В. І. Степаненка. Київ : KIM, 2012. 848 c.

2. Bordel-Gomez M. T., Miranda-Romero A., CastrodezaSanz J. Epidemiology of contact dermatitis: prevalence of sensitization to different allergens and associated factors. Actas Dermosifiliogr. 2010. No. 101 (1). P. 5975.

3. Науково-практичні рекомендації 3 утримання лабораторних тварин та роботи з ними / Ю. М. Кожем'якін та ін. Київ : Авіцена, 2002. 156 с.

4. Лікарські засоби. Належна лабораторна практика Київ : М-во охорони здоров'я України, 2009. 27 с.
5. Експериментальне вивчення нових препаратів для місцевого лікування ран : метод. рек. / Л. В. Яковлєва та ін. Харків : НФаУ, 2013. 52 с.

6. Савоськіна В. О. Оцінка клінічної есрективності застосування мазі «Вундехіл» у дерматології. Український журнал дерматології, венерології, косметології. 2019. 2. С. 75-80.

7. Бунятян Н. Д., Березнякова В. В., Глазкова Т. Ю. Эфрфективность $5 \%$ альтановой мази при контактном дерматите у крыс. Весник ВГУ. Серия : Химия. Биология. Фармация. 2004. 1. С. 160-162.

ISSN 2312-0967. Фармацевтичний часопис. 2021. № 3 
Фармакологічні дослідження біологічно активних речовин Pharmacological researches of biologically active substances

\section{References}

1. Stepanenko VI, editor. Dermatology, Venereology. [Дерматологія, венерологія] Kyiv: KIM; 2012. Ukrainian.

2. Bordel-Gomez MT, Miranda-Romero A, CastrodezaSanz J. Epidemiology of contact dermatitis: prevalence of sensitization to different allergens and associated factors. Actas Dermosifiliogr. 2010;101(1): 59-75.

3. Kozhemiakin YuM, Hromov OS, Filonenko MA, Saifetdinova HA. Scientific and practical recommendations for keeping laboratory animals and working with them. [Науково практичні рекомендації з утримання лабораторних тварин та роботи 3 ними] Kyiv: Avitsena; 2002. Ukrainian.

4. Medicinal Products. Good laboratory practice. [Лікарські засоби. Належна лабораторна практика]
Kyiv: Ministry of Health of Ukraine; 2009. Ukrainian.

5. lakovlieva LV, Tkachova OB, Butko YaO, Larianovska YuB. Methodical recommendations "Experimental study of new drugs for local treatment of wounds". [Експериментальне вивчення нових препаратів для місцевого лікування ран : метод. рек.] Kharkiv: NUPh Publishing House; 2013. Ukrainian.

6. Savoskina VO. [Evaluation of the clinical effectiveness of the use of ointment" Wundehil "in dermatology]. Ukr zhurn dermato, venerol, kosmetol. 2019;2: 75-80. Ukrainian.

7. Buniatian ND, Berezniakova VV, Hlazkova TYu. Efficacy of $5 \%$ altan ointment in contact dermatitis in rats. Vestnik VGU. Ser: Himiya, boil, farmats. 2004;1: 1602. Russian.

\section{Відомості про авторів}

Кошова О. Ю. - канд. фрармац. наук, старший науковий співробітник, доцент кафредри мікробіології, вірусології та імунології, Національний фрармацевтичний університет МОЗ України, Харків, Україна. E-mail: elenko926734@gmail. com, ORCID https://orcid.org/0000-0002-6601-3109.

Миргород В. С. - аспірантка кафедри косметології і аромології, Національний фрармацевтичний університет МОз України, Харків, Україна. E-mail: verunya113@gmail.com, ORCID https://orcid.org/0000-0001-2345-6789.

Башура О. Г. - д. фрармац. наук, професор, завідувач кафредри косметології і аромології, Національний фрармацевтичний університет МО3 України, Харків, Україна. E-mail: alkia2018@gmail.com, ORCID https://orcid. org/0000-0003-1896-9904.

Бобро С. Г. - канд. фрармац. наук, доцент кафедри косметології і аромології, Національний фрармацевтичний університет МО3 України, Харків, Україна. E-mail: svetabobro1@gmail.com, ORCID https://orcid.org/0000-0001-7933$107 X$.

Єрьомін О. П. - фрахівець навчально-наукової тренінгової лабораторії медико-біологічних досліджень, Національний фрармацевтичний університет МО3 України, Харків, Україна. E-mail: ereminfil@gmail.com, ORCID https://orcid. org/0000-0001-7300-0464.

\section{Information about the authors}

Koshova O. Yu. - PhD (Pharmacy), Associate Professor of the Department of Microbiology, Virology and Immunology, National University of Pharmacy of the Ministry of Health of Ukraine, Kharkiv, Ukraine. E-mail: elenko926734@gmail.com, ORCID https://orcid.org/0000-0002-6601-3109

Myrhorod V. S. - PhD-student of the Department of Cosmetology and Aromology, National University of Pharmacy of the Ministry of Health of Ukraine, Kharkiv, Ukraine. E-mail: verunya113@gmail.com, ORCID - https://orcid.org/0000-00012345-6789

Bashura O. G. - DSc (Pharmacy), Professor, Head of the Department of Cosmetology and Aromology, National University of Pharmacy of the Ministry of Health of Ukraine, Kharkiv, Ukraine. E-mail: alkia2018@gmail.com, ORCID https://orcid. org/0000-0003-1896-9904

Bobro S. G. - PhD (Pharmacy), Associate Professor of the Department of Cosmetology and Aromology, National University of Pharmacy of the Ministry of Health of Ukraine, Kharkiv, Ukraine. E-mail: svetabobro1@gmail.com, ORCID https:// orcid.org/0000-0001-7933-107X

Yeromin O. P. - Specialist of the Educational and Scientific Training Laboratory of Medical and Biological Research, National University of Pharmacy of the Ministry of Health of Ukraine, Kharkiv, Ukraine. E-mail: ereminfil@gmail.com, ORCID https://orcid.org/0000-0001-7300-0464 